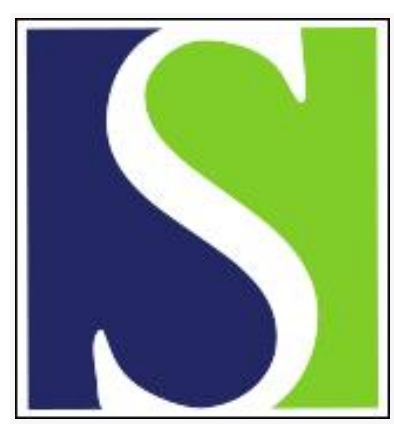

Scand J Work Environ Health 1975;1(2):117-119

https://doi.org/10.5271/sjweh.2857

Issue date: Jun 1975

Dissolution of silicic acid from amosite and quartz dusts under physiological conditions.

by Rahman Q, Beg MU, Viswanathan PN

Key terms: amosite; amosite dust; dust; experimental physiology; physiological conditions; quartz; quartz dust; silicic acid; toxicity

This article in PubMed: www.ncbi.nlm.nih.gov/pubmed/179135

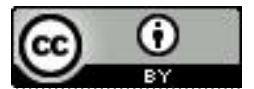




\title{
Dissolution of silicic acid from amosite and quartz dusts under physiological conditions
}

\author{
by QAMAR RAHMAN, Ph.D., M. U. BEG, Ph.D., and P. N. VISWANATHAN, Ph.D.1
}

\begin{abstract}
RAHMAN, Q., BEG, M. U. and VISWANATHAN, P. N. Dissolution of silicic acid from amosite and quartz dusts under physiological conditions. Scand. j. work environ. \& health 1 (1975) 117-119. The dissolution of silica from amosite dust in human serum and in Ringer buffer at $37^{\circ} \mathrm{C}$ was found to be significantly higher than that from quartz. The significance of this finding in relation to their fibrogenic effects has been discussed.
\end{abstract}

Key words: experimental physiology, silicic acid, amosite, quartz, dust, toxicity.

The fibrogenic response of guinea pig lung to amosite consists mainly of reticulin formation (9). Since asbestosis is considered to be a modified form of silicosis (3), the retarded collagen formation has been attributed to the nonavailability of sufficient silicic acid. The dissolution of silica from amosite was therefore studied by the present authors and compared with that of quartz, which produced pronounced collagen deposition in guinea pig lung (11) in a preliminary report.

\section{MATERIAL AND METHODS}

\section{Dusts}

The samples of dusts, amosite (fiber size below $30 \mu$ ) and quartz (particle size below $5 \mu$ ), were prepared according to the procedure described by Zaidi (11).

\section{Dissolution media}

The media employed for the dissolution of silicic acid were King's Ringer buffer, $\mathrm{pH}$ 7.4 (5) citrated human plasma, and human

1 Industrial Toxicology Research Centre, Lucknow, India.

Reprint requests to: Dr. Qamar Rahman, Industrial Toxicology Research Centre, Post Box No. 80, Lucknow- 226001, India. serum. The buffer solutions were sterilized by autoclaving, while plasma and serum were passed through a bacteriological filter.

\section{Experimental procedure}

Fifty milligrams of each of the dry dusts were accurately weighed in $15-\mathrm{ml}$ polyamide centrifuge tubes and autoclaved at 15 lbs of pressure for $15 \mathrm{~min}$. Ten milliliters of the respective media were added to each tube, and the tubes were subsequently stoppered tightly with sterilized polyamide caps and sealed with paraffin wax. A control set of tubes contained only the medium. The tubes were incubated at $37^{\circ} \mathrm{C}$ under sterile conditions. At zero time and after specified intervals, six tubes from each group were taken out and opened. The dust was removed by centrifugation at $12,000 \mathrm{~g}$ for $15 \mathrm{~min}$, and the supernatant was collected and measured. Silica was determined with the use of $1.0-\mathrm{ml}$ aliquots according to the method of King et al. (7).

\section{RESULTS}

As the period of incubation advanced, the dissolution of silica increased both from amosite and quartz (fig. 1). The dissolution was significantly greater from amosite 


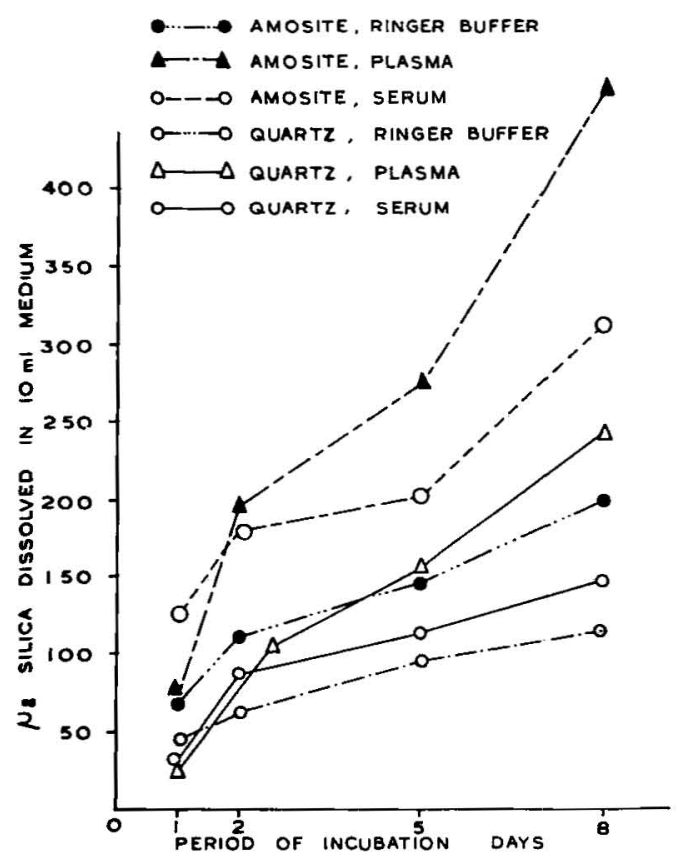

Fig. 1. Dissolution of silica from an $0.5 \%$ suspension of amosite and quartz dust in Ringer buffer, plasma, and serum at $37^{\circ} \mathrm{C}$. The arithmetic mean of six estimations is given. The data are expressed as $\mu \mathrm{g}$ silica dissolved in $10 \mathrm{ml}$.

than from quartz in all cases. Plasma eluted 424 and $243 \mu \mathrm{g}$ of silica, respectively, from $50 \mathrm{mg}$ of amosite and quantz in 8 days. The corresponding figures for serum were 371 and $233 \mu \mathrm{g}$. Since the amosite sample contained only $51 \%$ silica, this amounted to $1.67 \%$ of the available silica. The corresponding figure for quartz was $0.48 \%$ only. Dissolution of silica by Ringer buffer was only 45 to $55 \%$ of the level obtained with plasma or serum. With buffer also the rate of dissolution was significantly higher for amosite than for quartz.

\section{DISCUSSION}

Silica dissolution from quartz by ascitic fluid at $37^{\circ} \mathrm{C}$ was higher than that from asbestos (6), while the reverse was the case with water at $100^{\circ} \mathrm{C}$ (1). The present results indicate that the dissolution of silica from the amosite sample was faster than that from quartz at $37^{\circ} \mathrm{C}$. Morris et al. (8) observed that the elimination rates of amosite and silica from rat lung were similar. Since the dissolution of trace elements from asbestos was similar in human and bovine serum (2), the present data with human serum may be applicable to animal sera also. Thus amosite may be eliminated at a faster rate from guinea pig lung without the accumulation of silicic acid. An accumulation of mucopolyaccharide along with insufficient silicic acid, according to Holt and Went (4), favor reticulin formation rather than collagen deposition. The low fibrogenic effect of chrysotile was attributed to its faster elimination rate (10). Thus the absence of reticulin to collagen transformation in our earlier experiment in guinea pigs may be due to the quick elimination of the dust from the lungs.

\section{ACKNOWLEDGMENT}

The authors wish to express their gratitude to Dr. S. H. Zaidi, Director of the Industrial Toxicology Research Centre, for his interest in this investigation. Thanks are due to Mr. M. M. Lal for the supply of dusts and to Mr. S. D. Pandey for technical assistance.

\section{REFERENCES}

1. BRISCOE, H. V. A., MATHEWS, J. W., HOLT, P. F. and SANDERSON, P. M. A note on some new characteristic properties of certain industrial dusts. Bull. inst. min. metall. 391 (1937) 3-11.

2. CRALLEY, L. J., KEENAN, R. G., KUPEL, R. E., KINCED, R. E. and LYNEH, J. R. Characterization and solubility of metals associated with asbestos fibers. $A m$. ind. hyg. assoc. j. 29 (1968) 569-573.

3. HOLT, P. F. Asbestosis. In: P. F. HOLT (ed.), Pneumoconiosis. Edward Arnold Publishers, London 1957, pp. 143-159.

4. HOLT, P. F. and WENT, C. W. Studies on the nature of silicosis: A suggested mechanism of fibrogenesis. Br. j. ind. med. 17 (1960) 25-30.

5. KING, E. J. The solubility theory of silicosis: Critical study. Occup. med. 4 (1947) 26- 49 .

6. KING, E. J. and MC GEORGE, M. The biochemistry of silicic acid, the solution and excretion of silica. Biochem. $j .32$ (1938) $417-425$.

7. KING, E. J., STACY, B. D., HOLT, P. F., YATES, D. $M$. and PICKLES, D. The colorimetric determination of silicon in the macro analysis of biological and mineral dusts. Analyst 80 (1955) 441- 453. 
8. MORRIS, T. G., ROBERT, W. H., SILVERTON, R. E., SKIDMORE, J. W., WAGNER, J. C. and COOK, G. W. Comparison of dust retention in specific pathogen free and standard rats. In: C. N. DAVIES (ed.), Inhaled particles and vapours (2nd ed.). Pergamon Press, Oxford 1967, pp. 205-213.

9. VISWANATHAN, P. N., DOGRA, R. K. S., SHANKER, R. and ZAIDI, S. H. Pul- monary fibrogenic response of guinea pigs to amosite dust. Int. Arch. Arbeitsmed. 31 (1973) $51-59$.

10. WAGNER, J. C. and SKIDMORE, J. W. Asbestos dust deposition and retention in rats. Ann n.y. acad. sci. 132, 77-86.

11. ZAIDI, S. H. Experimental pneumoconiosis. Johns Hopkins Press, Baltimore, Md. 1969. pp. 35-41, 98-103, 162-163.

Received for publication: 1974-08-12 